\title{
Natural Gas Pricing Based On Social Costs of Carbon: A Case Study of Kerman Province
}

\author{
Zeinolabedin Sadeghi ${ }^{1}$ \\ Seyyed Abdolmajid Jalaei ${ }^{2}$ \\ Mahla Movahedi ${ }^{3}$
}

z_sadeghi@uk.ac.ir

jalaee@uk.ac.ir

\begin{abstract}
Due to the increasing demand for natural gas and its benefit of producing less carbon compared to other fossil fuels, pricing the natural gas based on the social expenses is becoming necessary more than ever. Accordingly, presenting models that enable us to find coordination between natural gas pricing and the final cost of carbon reduction is of high importance. This study aims to find the relationship between natural gas pricing, carbon rent, and the degree of pollution caused by natural gas. To this end, the final cost of $\mathrm{CO} 2$ reduction for two carriers of natural gas and gas oil in Kerman province has been calculated; Then the measures of social costs based on carbon expenses for natural gas and gas oil in 3 sections of the power plant, industry and houses is conducted. This study presents the evaluation of the final cost of carbon caused by natural gas and gas oil for the three mentioned sectors. The results indicate that the final costs of carbon caused by natural gas are always lower than the final costs of carbon caused by gas oil. This is the major reason as to why the social costs of natural gas are lower than of gas oil in the three sectors. Moreover, the results show that there is not a significant difference between the rates of the final cost of natural gas and the price of natural gas delivery to the end-users in 2013-2016. This is due to the little amount of pollution natural gas produces and the relatively low cost of its pollution. However, the rate of delivery cost to the power plant is 8 percent of social costs and 9 percent of the final costs of natural gas.
\end{abstract}

Keywords: Abatement Cost of Carbon Dioxide, Natural Gas Pricing, Shadow Price, Distance Function, Data Envelopment Analysis.

JEL Classification: Q52, Q41, Q46.

\footnotetext{
1. Associate Professor, Department of Economics, Shahid Bahonar University of Kerman, Kerman, Iran (Corresponding Author).

2. Professor, Department of Economics, Shahid Bahonar University of Kerman, Kerman, Iran.

3. M.A in Energy Economics, Shahid Bahonar University of Kerman, Kerman, Iran.
} 


\section{قيمتخذارى كَاز طبيعى بر مبناى هزينههاى اجتماعى ناشى از كربن: مطالعه موردى استان كرمان}

z_sadeghi@uk.ac.ir |

زين العابدين صادقى

مانشيار كروه اقتصاد دانشًاه شهيد باهنر كرمان، كرمان، ايران

(نويسندهمسئول).

jalaee@uk.ac.ir

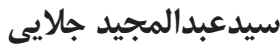

استاد گروه اقتصاد دانشعاه شهيد باهنر كرمان، كرمان، ايران.

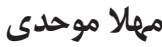

دانشآموخته كارشناسى ارشد اقدئ اقتصاد انرزى، دانشعاه شهيد

مقاله بزوهشى

باهنر كرمان، كرمان، ايران.

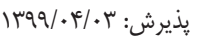

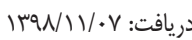

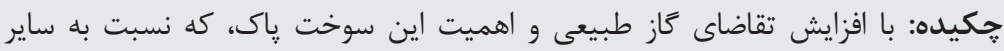

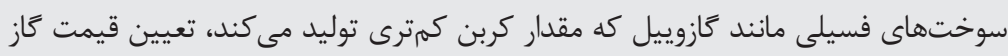

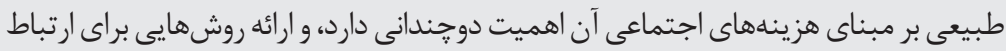

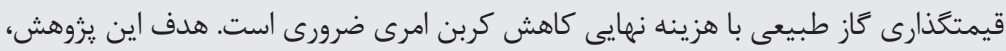

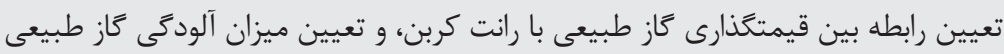

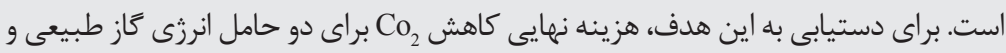

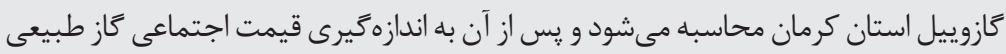

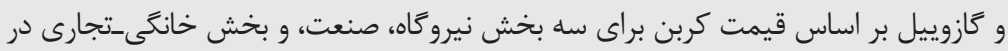

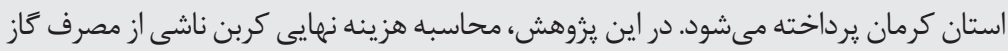

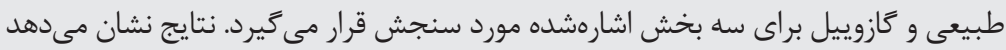

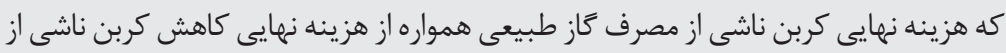

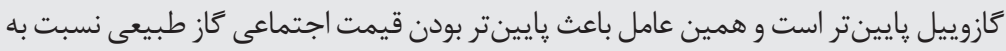

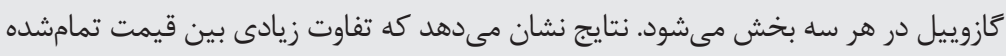

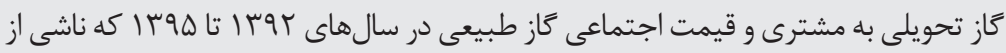

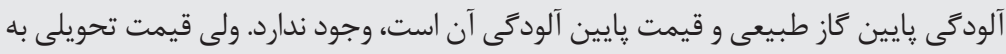

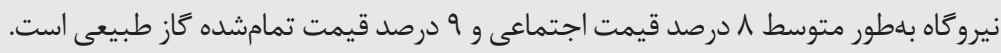
كليدوازهها: هزينه كاهش دىاكسيد كربن، قيمتحذارى كاز طبيعى،قيمت سايهاى، تابع فاصلهاى، تحليل يوششى دادهها.

طبقهبندى Q Q 
ايران اولين دارنده ذخاير گازى، سومين مصرفكننده بزرى كاز، و جهارمين توليدكننده گاز جهان

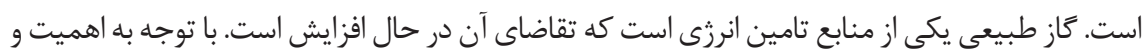

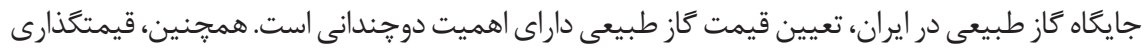

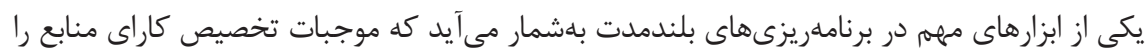

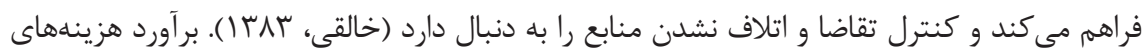
اجتماعى انتشار عازهاى SOX تعديل ضرايب جهانى موجود و مرتبط توسط رحيمى و همكاران (بوسا ) انجام شده است. لطفعلىيور

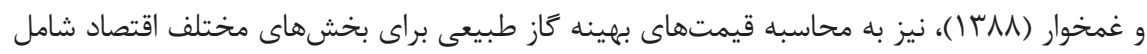

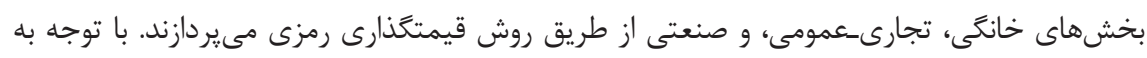

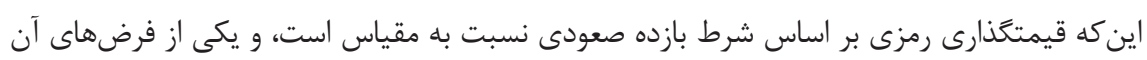

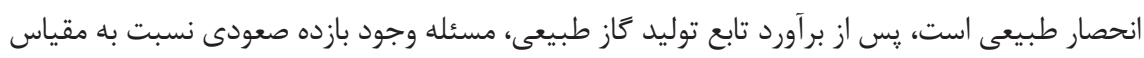

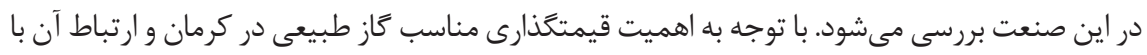

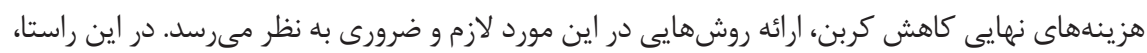
سهمم كاز طبيعى به عنوان سوخت در حال افزايش است. كاز طبيعى منبع انرزى تقريباً پاكيزه، فراوان، و و

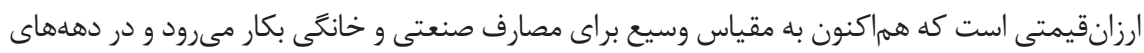
آينده بهرهبردارى از آن گسترش مى يابد. در توسعه اقتصادى جهان، مناطق و كشورهاى مختى مختلف، به دهائ دليل

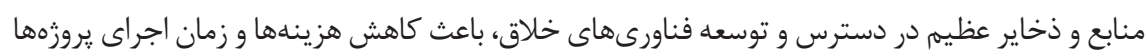

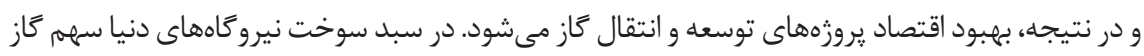

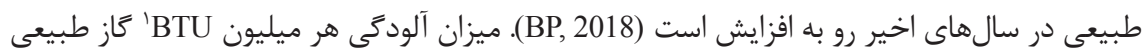

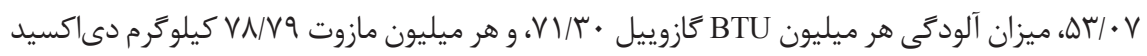

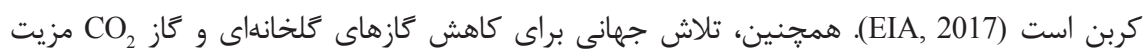

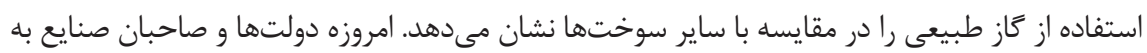
دنبال آن دسته از حاملهاى انرزى هستند كه آلايندهاى كمترى توليد مى كنيند. به همين دليل، جهان

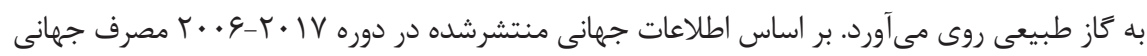

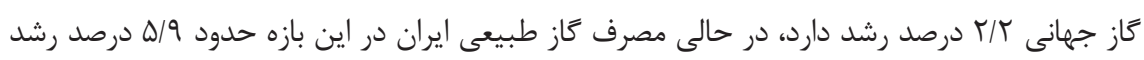




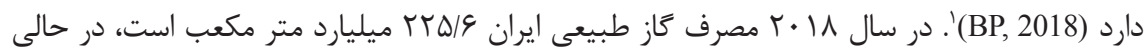

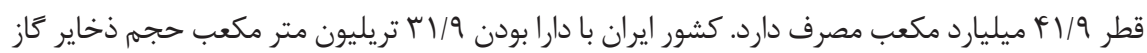

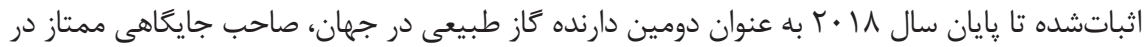

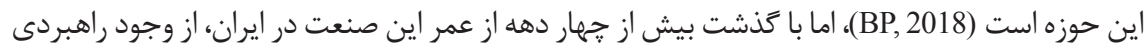

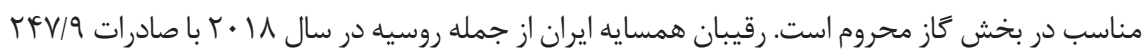

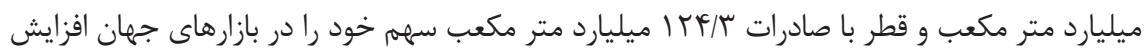

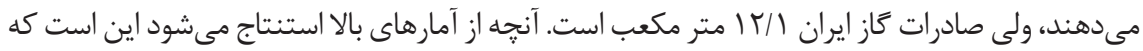

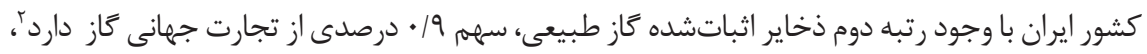

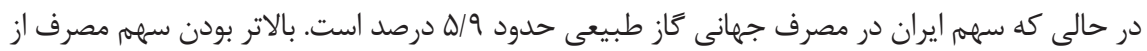
تجارت اين واقعيت را نشان مى دهد كه ايران به دليل نبود زيرساختارهاى تجارت كاز طبيعى سعى مى كند

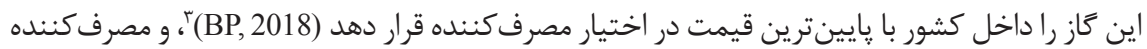
اطلاع جندانى از قيمت صادرات و رانت كربن اين حامل سبز ندارد.

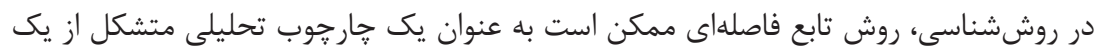
خانواده از مدلها در نظرگرفته شود. قيمت سايهاى خروجى نامطلوب از رابطه دو أنكى (همزادى)، بين تابع فاصلهاى و درآمد، هزينه يا تابع سود بهدست مى آيد، و تابع فاصلهاى توصيفى از رابطه

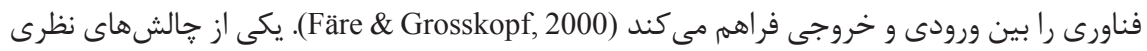
و تجربى در ادبيات اقتصادى ايران توجه نكردن به قيمتخذارى حاملهاى انرزى بر اساس عوارض برض خارجى اين حاملهاست. در اين يزوهش، هزينه نهايى كاهش

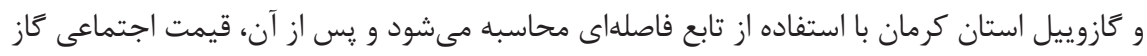
طبيعى و كازوييل بر اساس رانت كربن بهدست مى بـ آيد.

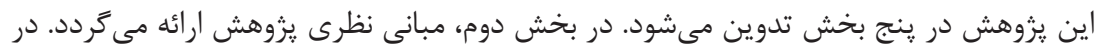

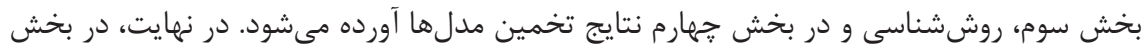

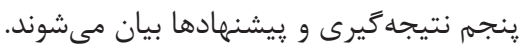

1. شاخصهاى تحليل رشد بر اساس گزارش

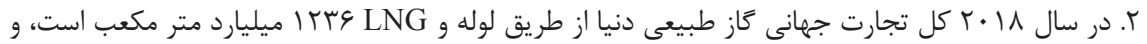
ايران / T/ ا ميليارد متر مكعب صادرات داشته است. 


\section{مبانى نظرى يزووهش}

در دنياى آرمانى، رقابت كامل عمل متقابل هزاران توليدكنندة بيشينه كننده سود و هزاراران

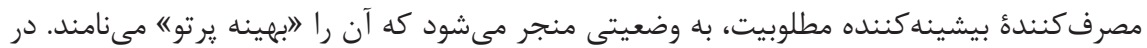

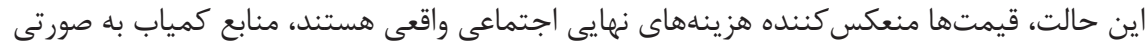

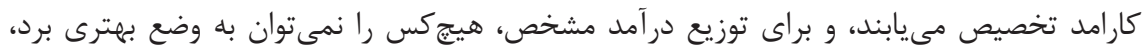

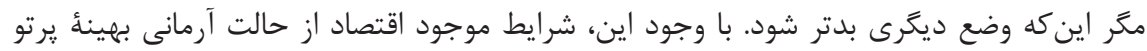

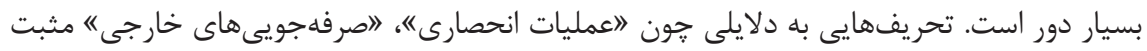

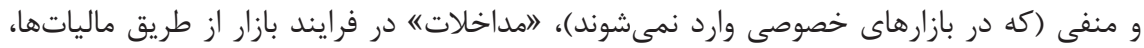

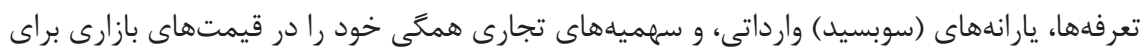

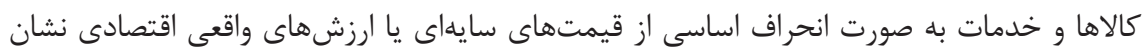

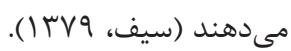

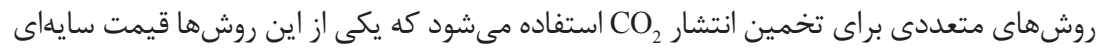

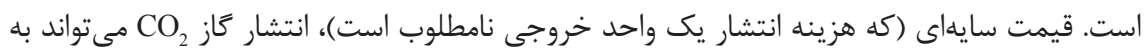

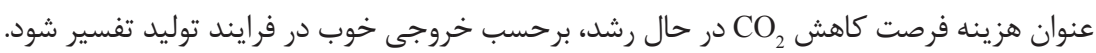

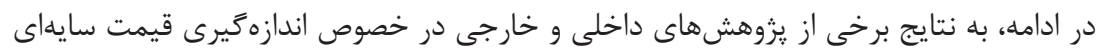

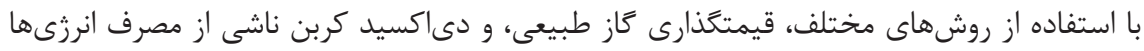

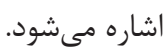

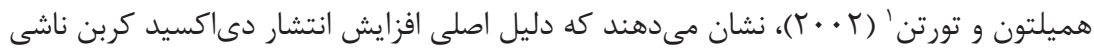

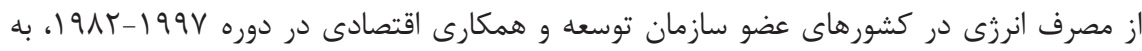

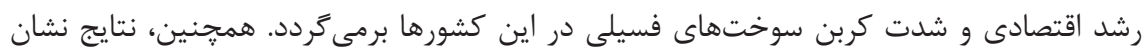

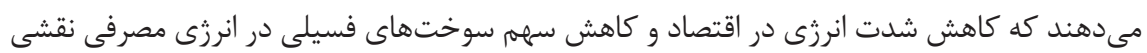

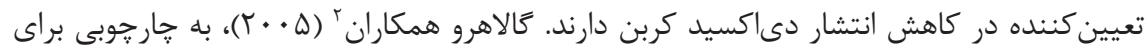

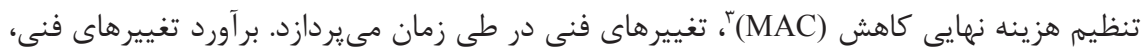

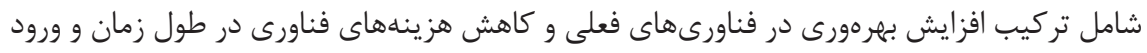

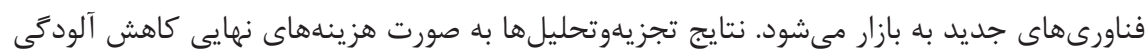

1. Hamilton \& Turton

2. Gallaher et al.

3. Marginal Abatement Cost 


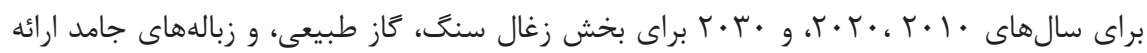

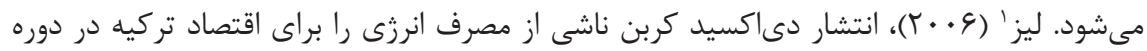
ץ. • ץ-•191 مورد بررسى قرار مىدهد. نتايج وى نشان مىدهد كه رشد اقتصادى نقشى حياتى در انتشار دىاكسيد كربن دارد، و شدت كربن و تغيير در تركيب اقتصاد همسو با تغييرهاى انتشار

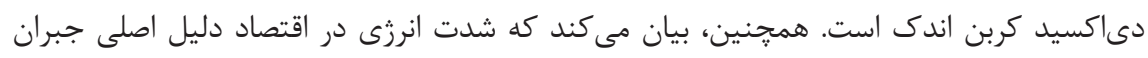

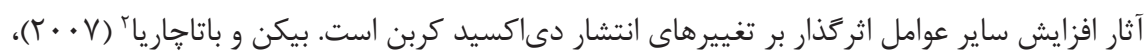

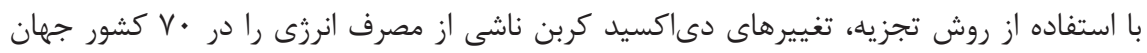

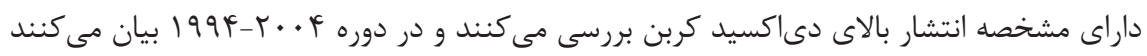

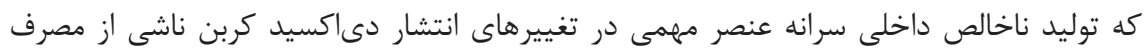
انرزى است. همجنين، نشان مى دهند كه تركيب سوخت فسيلى اثر منفى اندكى بر تغييرهاى انتشار دى اكسيد كربن دارد، در حالى كه سهم سوختهاى فسيلى در كل انرزى مصرفى در تغييرهاى انتشار

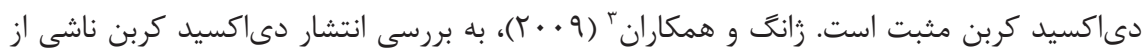

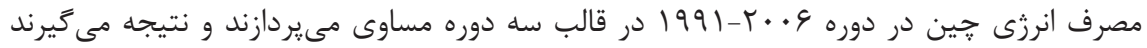
كه فعاليت اقتصادى جين عامل اصلى در تغييرهاى انتشار دىاكسيد كربن در كل اقتصاد و در همه بخشهاى اقتصاد است و دليل اصلى كاهش تغييرها در انتشار دىاكسيد كربن ناشى از مصرف انرزى به بهبود شدت انرزى در اقتصاد اين كشور است. همجنين، نشان مىدهند كه تغييرهاى ساختارى در بخشهاى مختلف اقتصادى اثر اندكى بر تغييرهاى انتشار دىاكسيد كربن دارد. از نظر وانت و

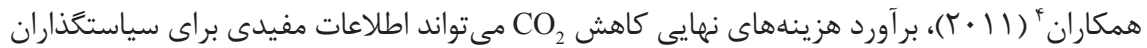

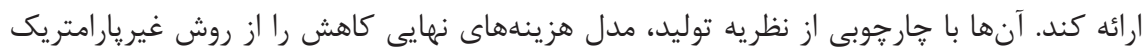
و تجربى بهدست مى آورند، و معتقد هستند كه دو راهبرد براى كاهش

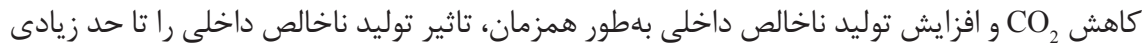

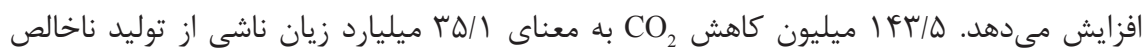

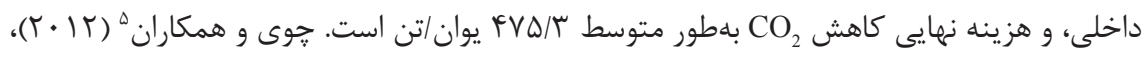
روش تحليل غيريارامتريك كارايى را براى تخمين كارايى انرزى، كاهش انتشار، هزينه نهايى انرزى، و

1. Lise

2. Bacon \& Bhattachrya

3. Zhang et al. 
نسبت انتشار CO در خين بررسى مى كنند، و از مدل غيرمحورى اسلاكس' بر اساس تحليل يوششى

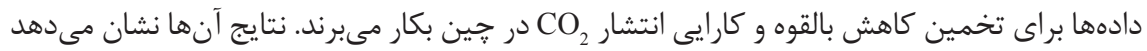
كه ميانگين كاهش انتشار $\mathrm{CO}_{2} \mathrm{CO}_{2}$ براى كل كشور است. لى و زوّ (ها •r)، تخمين جهتدار قيمت سايهاى صنعت زغال سنَ ايالات متحده آمريكا بررسى مى كنند. و روش بهرهورى نهايى جهت ردار (DMP)

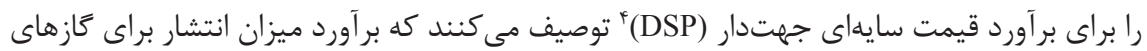

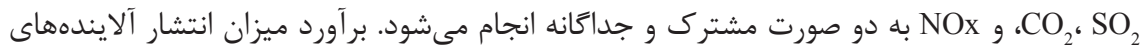

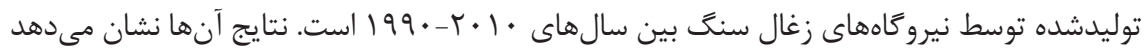

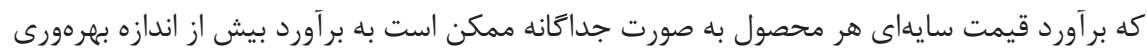

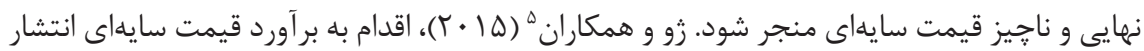

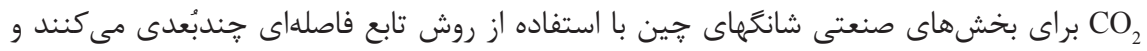

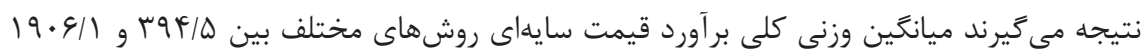

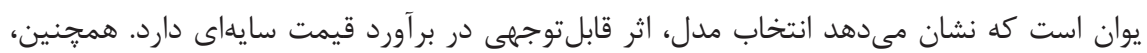

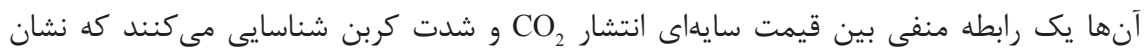

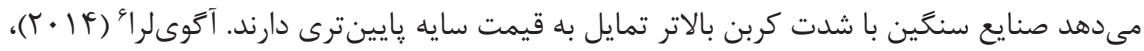

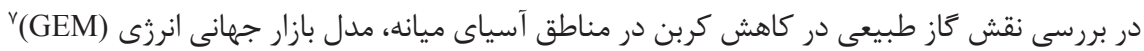

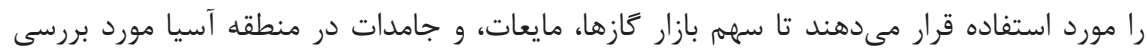
قرار گَيرد. او نتيجه گيرى مى كند كه منطقة آسيا داراى منابع كاز طبيعى وسيع است كه براى توسعه

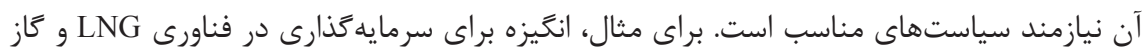

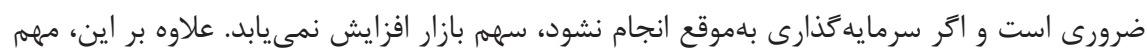

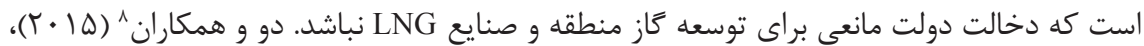

\section{Slacks}

2. Lee \& Zhou

3. Directional Marginal Productivity

4. Directional Shadow Prices

5. Zhou et al.

6. Aguilera

7. Global Energy Market Model

8. Du et al. 
به برآورد منحنى هزينه نهايى كاهش (MACC)' انتشار CO در جين بر اساس ينل استانى در دوره

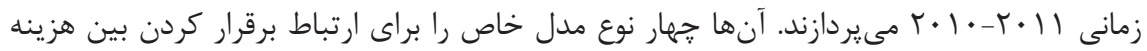

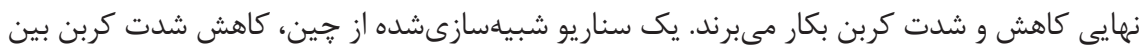

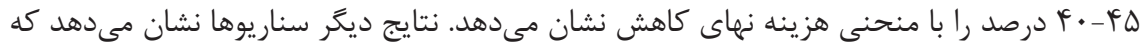

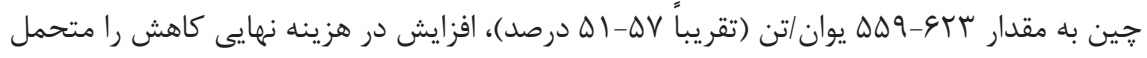

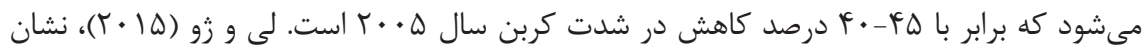
مى دهند كه قيمت سايهاى و هزينه نهايى كاهش، رهنمودهاى بارزشى رابى را براى حمايت از سياستهاى

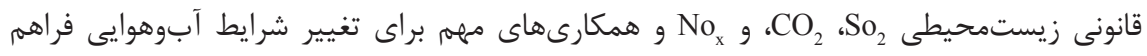

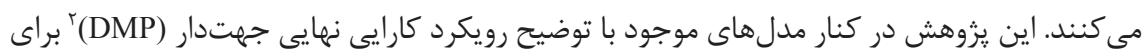

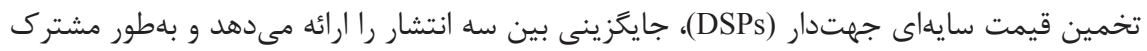

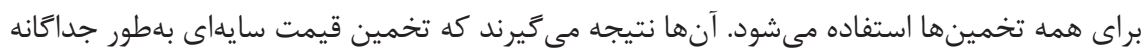

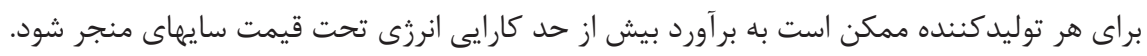

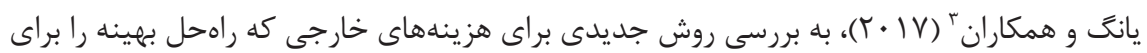
توزيع كاز طبيعى نشان مىدهد، مى يردازند. در واقع، توزيع منطقهاى كاز طبيعى و ساير منابع انرزى با هدف كمينهسازى هزينه هاى خارجى و اقتصادى، بهينهسازى مى شود. آنها نشان مى مدهند كه

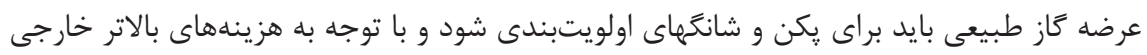

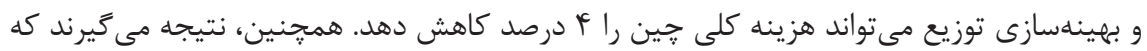

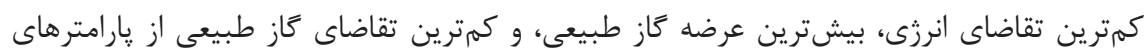

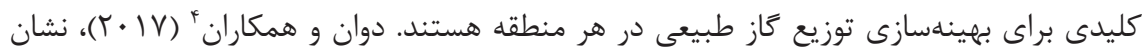

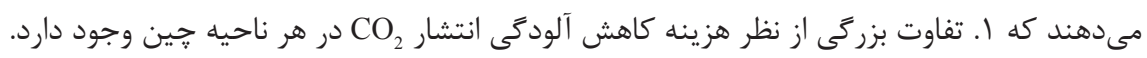
قيمتسايهاى در ناحيه شرقى ساحلى بلهطور قابلتوجهى بالاتر از ديخر استانهاى شرقى است و

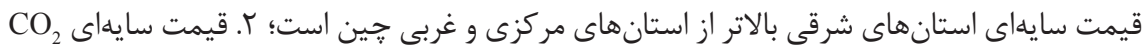
صنعت فولاد و آهن در بيشتر نواحى، سال به سال به سمت يايين متمايل است؛ و ب. قيمت سايهاى

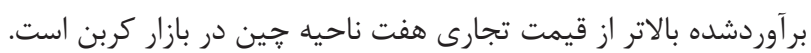

1. Marginal Abatement Cost Curve

2. Directional Marginal Productivity 


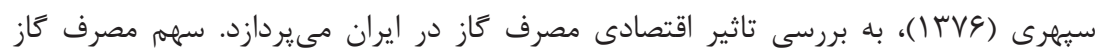

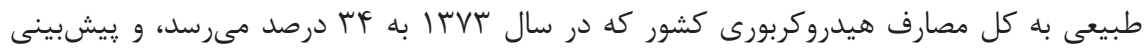

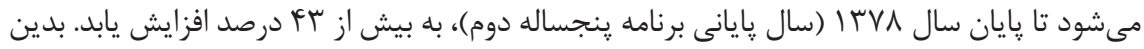
ترتيب، حدود •^ درصد جمعيت شهرى كشور ايران زير يوشش شبكه گاز طبيعى قرار مى گيرند. شاخص مصرف سرانه انرزى بهطور معمول در جوامع درحالتوسعه كمتر از جوامع توسعهيافته است.

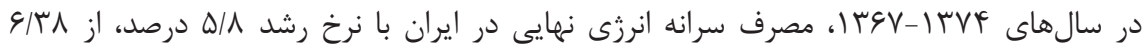
بشكه معادل نفت خام، به 9/ه بشكه معادل نفت خام مىرسد كه حاكى از مصرف بالاى سرانه انرزى

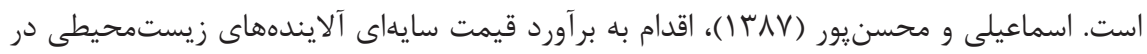

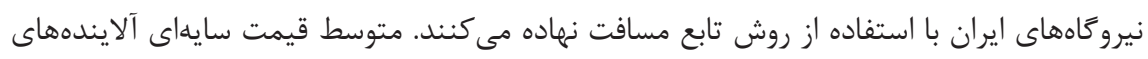

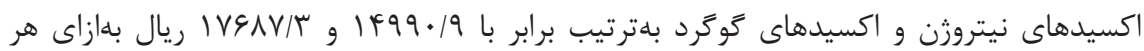

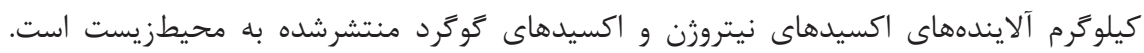

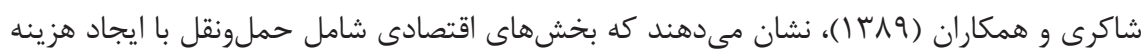

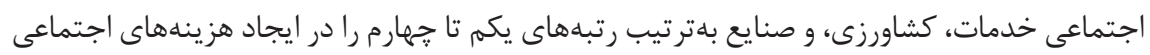

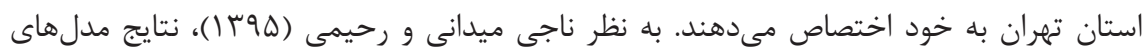

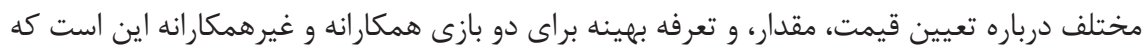
نفع كشورهاى عضو در بازى همكارانه بلمراتب بيشتر از بازى غيرهمكارانه است. اوحدى و و همكاران

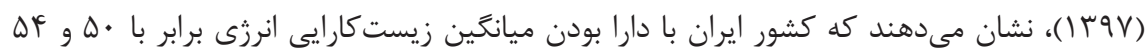

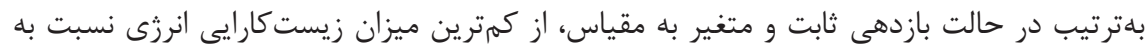

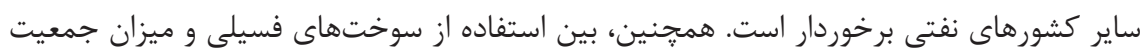

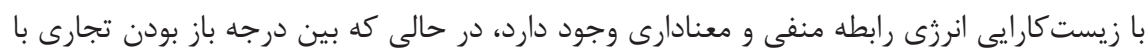

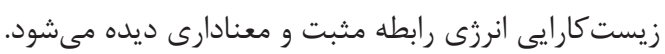

\section{روش}

براى برآورد قيمت سايهاى از توابع فاصلهاى با تحليل يوششى دادهها از نسخه سب نرمافزار كمز'

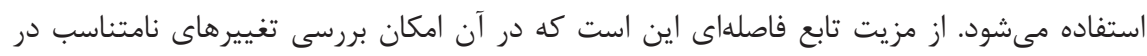
خروجى ها وجود دارد، زيرا افزايش خروجى هاى خوب را امكان يذير ميىسازد، و همزمان خروجى هاى إنى 


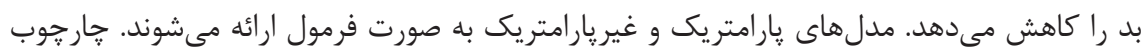

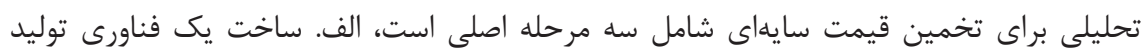

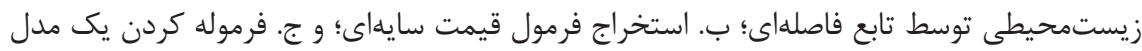
يارامتريك/ نايارامتريك براى محاسبه قيمت سايهاى.

\section{روشهاى بر آورد قيمت سايهاى}

\section{فناورى توليد زيستمحيطى}

فرض كنيد يك واحد توليدى كه با استخدام سرمايه (k)، نيروى كار (1)، و انرزى (e) هر دو محصول مطلوب (y) و محصول نامطلوب (b) را توليد مى كند: $(y, b) \in R_{+}^{2}$

فرايند توليد مشترك مىتواند توسط يك فناورى توليد زيستمحيطى مدلسازى شود، كه به دو

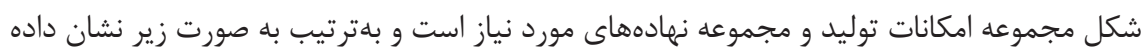

$$
\begin{aligned}
& p(x)=\{u: \text { : توليدكننده u } x\} \\
& I(u)=\{x: \text { براى توليدu بهx نياز است }\}
\end{aligned}
$$

در نظريه توليد با جند خروجى، ورودىها و خروجىهاى مطلوب اغلب با قابليت دسترسى قوى' تصور مىشوند، در حالى كه خروجىهاى (مطلوب و نامطلوب)، با قابليت دسترسى ضعيف؟ تصور مىشوند (Färe et al., 2005). قابليت دسترسى قوى نشان مى دهدي كه ورودى (يا خروجى مطلوب)، را مى توان بدون تحمل هر گونه هزينه، كاهش يا افزايش داد. قابليت دسترسى ضعيف بر توليد مشترى

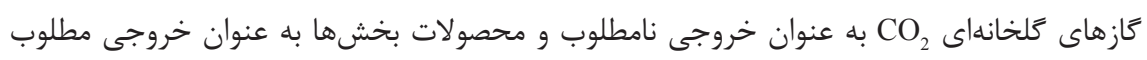
تحميل مىشود. براى مثال:

$(y, b) \in p(x), g_{0} 0 \leq \theta \leq 1 \rightarrow(\theta y, \theta b) \in p(x)$, 
كه نشان مىدهد كاهش خروجىهاى نامطلوب (كازهاى كلخانهاى)، مستلزم كاهش متناسب خروجى مطلوب (محصولات بخشهاى مختلف) است. اين شرايط نشان مىدهد كه توليد خروجى هاى

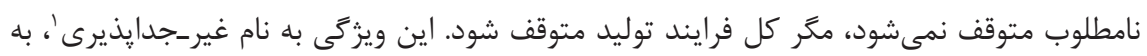
صورت زير بيان مىشود:

$(y, b) \in p(x), b=0 \rightarrow y=0$

فناورى توليد زيستمحيطى مى تواند بهطور كامل توسط تابع فاصلهاى جهتدار يا تابع فاصلهاى شفارد؟ مشخص شود. تابع فاصلهاى شفارد در دو نسخه متداول، يعنى تابع فاصلهاى خروجى و ورودى شئ شفارد استفاده

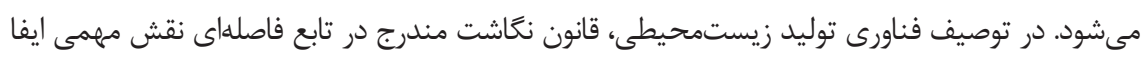

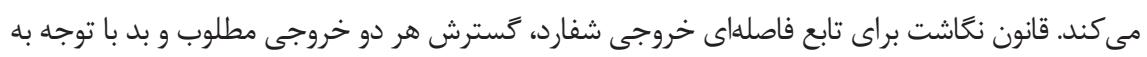

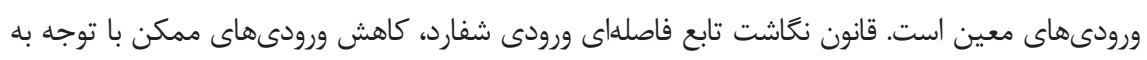

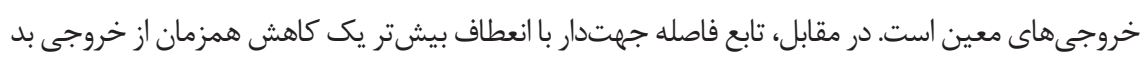

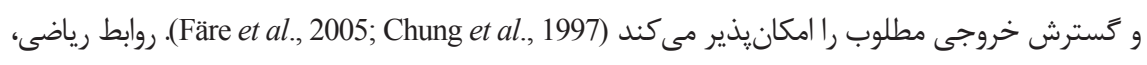
توابع فاصلهاى خروجى شفارد، ورودى شفارد، و توابع فاصلهاى جهت دار خروجى مرنى بلهترتيب نشان داده مىشوند:

$D_{0}(\mathrm{x}, \mathrm{u})=\inf \left\{\theta:\left(\frac{\mathrm{u}}{\theta}\right) \in \mathrm{p}(\mathrm{x})\right\}$

$D_{i}(u, x)=\sup \left\{\delta:\left(\frac{\mathrm{x}}{\delta}\right) \in \mathrm{I}(\mathrm{u})\right\}$

$\vec{D}_{0}\left(x, y, b ; g_{y}, g_{b}\right)=\operatorname{SUP}\left\{\beta:\left(y+\beta g_{y}, b-\beta g_{b}\right) \in p(x)\right\}$

در معادله بالا، $\left(g_{y}, g_{b}\right)$ بردار جهتدار تعيينشده براى تابع فاصلهاى جهتدار است و بردارهاى

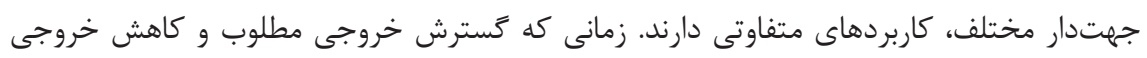

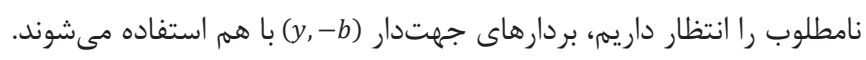

\section{استخراج فرمول قيمت سايهاى}

يس از استخراج فناورى توليد با استفاده از توابع فاصلهاى، مرحله دوم استخراج فرمول قيمت

1. Null-Jointness

2. Shephard 
سايهاى از فناورى توليد زيستمحيطى است. رابطه دوگانكَى بين تابع فاصلهاى و درآمد، هزينه يا تابع

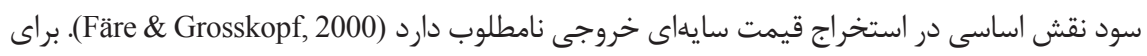

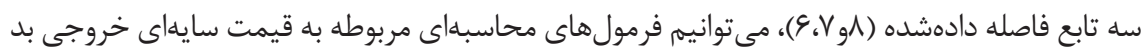
را با استفاده از روشهاى لاكرانز و لم دو كانه شفارد استخراج كنيم (Hailu \& Veeman, 2000).

$$
\begin{aligned}
& \mathrm{r}_{\mathrm{b}}=\mathrm{r}_{\mathrm{y}} \cdot \frac{\partial \mathrm{D}_{0}(\mathrm{x}, \mathrm{u}) / \partial \mathrm{b}}{\partial \mathrm{D}_{0}(\mathrm{x}, \mathrm{u}) / \partial \mathrm{y}} \\
& \mathrm{r}_{\mathrm{b}}=\mathrm{r}_{\mathrm{y}} \cdot \frac{\partial \mathrm{D}_{\mathrm{i}}(\mathrm{u}, \mathrm{x}) / \partial \mathrm{b}}{\partial \mathrm{D}_{\mathrm{i}}(\mathrm{u}, \mathrm{x}) / \partial \mathrm{y}} \\
& r=r_{y} \cdot \frac{\partial \vec{D}_{0}\left(x, y, b ; g_{y},-g_{b}\right) / \partial b}{\partial \vec{D}_{0}\left(x, y, b ; g_{y},-g_{b}\right) / \partial y}
\end{aligned}
$$

كه در آنها مىشود كه ry برابر با قيمت بازارىاش است. بيانِ كسرى در سمت راست معادلههاى بالا، نرخ نهايى

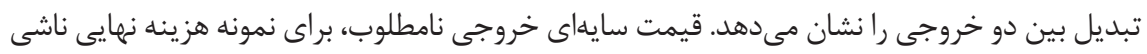
از تحميل قابليت دسترسى ضعيف يا هزينه فرصت كاهش اين خروجى برحسب كاهش خروجى رئى مطلوب

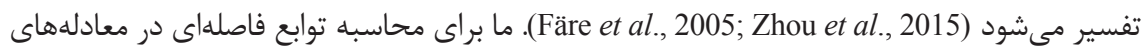

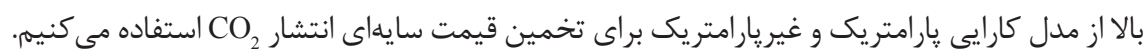

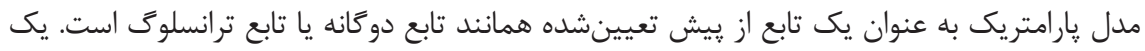

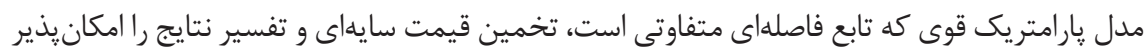

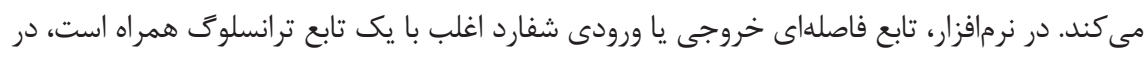

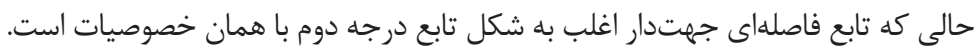

\section{روش هاى تخمين قيمت سايهاى آلودىى}

دو روش تخمين يارامتريك و غير يارامتريك در بررسى تابع فاصلهاى استفاده مىشوند. در اين يزوهش از

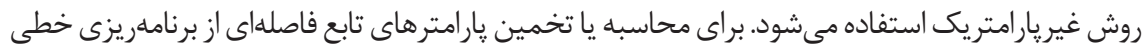

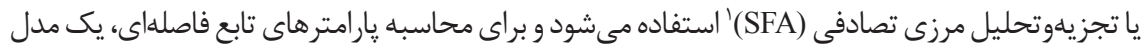


برنامهريزى خطى مشخص مىشود. هدف، يِدا كردن مجموعهاى از يارامترها براى كمينهسازى مجموع انحراف مقادير تابع فاصلهاى از مرز فناورى توليد زيستمحيطى است. شرايط محدوديت امكانسنجى،

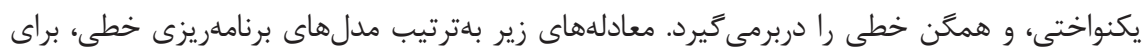
محاسبه يارامترهاى خروجى شفارد، ورودى شفارد، و تابع فاصلهاى جهتدار را نشان مىدهدي:

$$
\begin{aligned}
& \operatorname{Max} \sum_{n}\left[\ln D_{0}\left(x^{n}, u^{n}\right)-\ln 1\right] \\
& \text { s.t. } \quad \ln D_{0}\left(x^{n}, u^{n}\right) \leq 0 ; \\
& \quad \ln D_{0}\left(x^{n}, u^{n}\right) / \partial \ln y^{n} \geq 0 ; \\
& n D_{0}\left(x^{n}, u^{n}\right) / \partial \ln b^{n} \leq 0 ; \\
& \quad \partial \ln D_{0}\left(x^{n}, u^{n}\right) / \partial \ln x^{n} \leq 0 ; \\
& \sum_{j} \alpha_{j}=1, \sum_{j} \sum_{j} \gamma_{j j^{\prime}}=\sum_{i} \sum_{j} \beta_{i j}=0
\end{aligned}
$$

$$
\begin{aligned}
& \gamma_{i i \prime}=\gamma_{i{ }^{\prime}}, i \neq i^{\prime} ; \gamma_{j j^{\prime}}=\gamma_{j^{\prime} j}, j \neq j^{\prime} ; \\
& \operatorname{Min} \sum_{n}\left[\ln D_{i}\left(x^{n}, u^{n}\right)-\ln 1\right] \\
& \text { s.t. } \ln D_{i}\left(x^{n}, u^{n}\right) \geq 0 ; \\
& \quad \ln D_{i}\left(x^{n}, u^{n}\right) / \partial \ln y^{n} \leq 0 ; \\
& \partial \ln D_{i}\left(x^{n}, u^{n}\right) / \partial \ln b^{n} \geq 0 ; \\
& \partial \ln D_{i}\left(x^{n}, u^{n}\right) / \partial \ln x^{n} \geq 0 ; \\
& \sum_{i} \alpha_{i}=1 ; \sum_{i} \sum_{i^{\prime}} \gamma_{i i^{\prime}}=0 ; \sum_{i} \sum_{j} \beta_{i j}=0 \\
& \gamma_{i i^{\prime}}=\gamma_{i{ }^{\prime}}, i \neq i^{\prime} ; \gamma_{j j^{\prime}}=\gamma_{j^{\prime} j}, j \neq j^{\prime} ;
\end{aligned}
$$

$$
\begin{aligned}
& \operatorname{Min} \sum_{n}\left[\vec{D}_{0}\left(x^{n}, y^{n}, b^{n} 1,-1\right)-0\right] \\
& \text { s.t } \vec{D}_{0}\left(x^{n}, y^{n}, b^{n} 1,-1\right) \geq 0 ; \\
& \partial \vec{D}_{0}\left(x^{n}, y^{n}, b^{n} 1,-1\right) / \partial y^{n} \leq 0 ; \\
& \partial \vec{D}_{0}\left(x^{n}, y^{n}, b^{n} 1,-1\right) / \partial b^{n} \geq \\
& \partial \vec{D}_{0}\left(x^{n}, y^{n}, b^{n} 1,-1\right) / \partial x^{n} \geq 0 ; \\
& \alpha_{m}-\alpha_{k}=-1 ; \gamma_{1}=\gamma_{2}=\gamma_{3} \\
& \sum_{i} \mu_{i 1}=\sum_{i} \mu_{i 2} \\
& \gamma_{i i^{\prime}}=\gamma_{i \prime}, i \neq i^{\prime}
\end{aligned}
$$


روش غيريارامتريك شفارد يا تابع فاصلهاى جهتدار مىتواند با تجزيهوتحليل يوشش دادهها

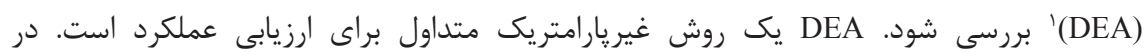
يزوهشهاى انرزى و زيستمحيطى به صورت وسيعى در ارزيابىهاى عملكرد پايهاى انرزى و انتشار

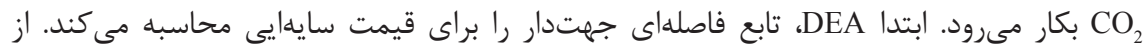
DEA برنامهريزى خطى حل مىشود. روش غير يارامتريك DEA نيز مىتواند براى محاسبه قيمت سايهاى

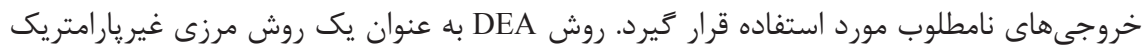

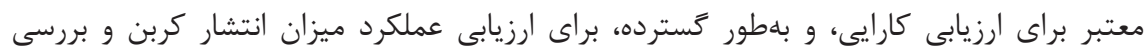

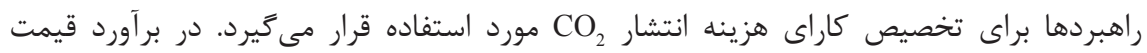

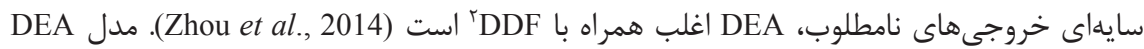
غير يارامتريك به صورت مدل (ه (1) است:

$\vec{D}(x, y, b ; 1,-1)=\max \beta$

s.t $\sum_{i=1}^{k} \lambda_{i} y_{i} \geq(1+\beta) y^{n}$

$\sum_{i=1}^{k} \lambda_{i} b_{i}=(1-\beta) b^{n}$

$\sum_{i=1}^{k} \lambda_{i} x_{i} \leq x^{n}$

$\beta \geq 0 ; \lambda_{i} \geq 0, i=1,2, \ldots k$

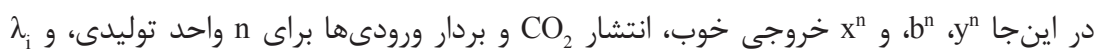
متغيرهاى شدت هستند. در اين معادله، اثر برابرى علامت بر محدوديت انتشار CO بازتابى از فرض بـ بـ

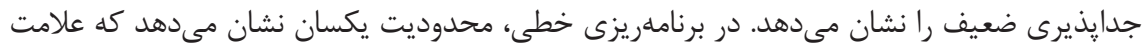

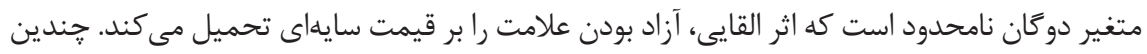

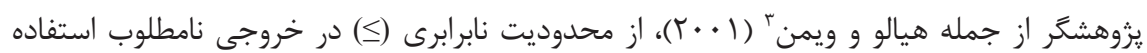
مى كنند كه مىتواند برآوردى از قيمت سايهاى را با يك علامت مثبت ايجاد كند. از لحاظ نظرى،

1. Data Envelopment Analysis

2. Directional Distance Function

3. Hailu \&Veemen 
محدوديت نابرابرى باطور ضمنى خروجىهاى نامطلوب را به عنوان ورودىهايى كه ممكن است روند توليد واقعى را منعكس نكند، مورد بررسى قرار مى دهد. فرمول معادله DEA به عنوان رابطه متغيرهاى دوكانه براى محدوديتهاى خروجى هاى بد و خوب در معادله (1) محاسبه مىشود. با اين حال لى و زو (ه ( • )، استدلال مى كنند كه مشاهدههايى كه از همان نقطه مشابه مرزى برخوردارند (معادله ع) )،

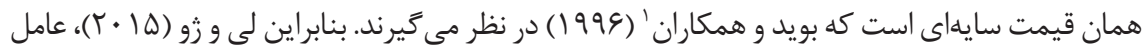
همبستكى ناكارايى و فرمول قيمت سايهاى را به صورت زير تصحيح مى كنند:

$r_{b}=-r_{y} \cdot \frac{\partial \vec{D}_{0}\left(x, \sigma_{y} y, \sigma_{b} b ; 1,-1\right) / \partial\left(\sigma_{b} b\right)}{\partial \vec{D}_{0}\left(x, \sigma_{y} y, \sigma_{b} b ; 1,-1\right) / \partial\left(\sigma_{y} y\right)} \cdot \frac{\sigma_{b}}{\sigma_{y}}$

در حالى كه

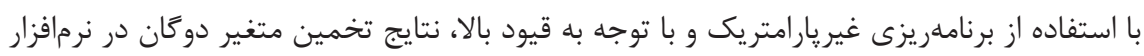

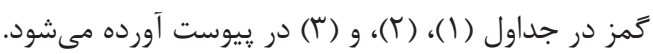

\section{محاسبه انتشار دىاكسيدكربن (Co)}

براى محاسبه انتشار دىاكسيد كربن در هر بخش از فرمول (IV) استفاده مىشود.

$C E_{\mathrm{ff}}=\sum_{\mathrm{i}=1}^{\mathrm{nfc}}\left(\mathrm{FC}_{\mathrm{i}} \times \mathrm{EF}_{\mathrm{i}}\right)$

بيانكر كل ارزش حرارتى از نوع سوخت iام با واحد BCU نوع سوخت il بام با واحد بيانكر ميزان كل انتشار آلاينده CO ناشى از مصرف سوختهاست. ضريب انتشار هر نوع از سوخت

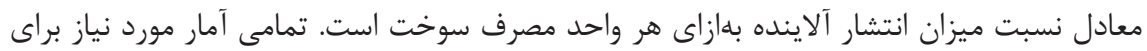

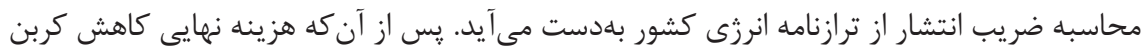
براى هر بخش بلهست آمد، بر اساس قيمت تمامشده هر بخش برحسب مصرف عاز و كازوييل (به

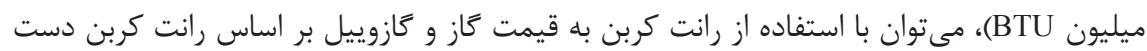


رانت كربن براى هر بخش از فرمول زير محاسبه مىشود:

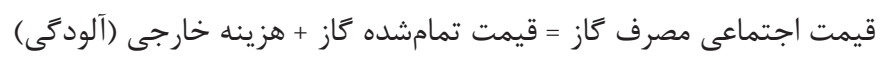

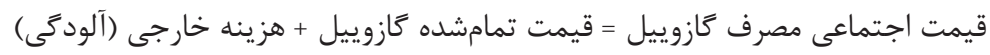

رانت = تفاوت بين قيمت اجتماعى دو حامل انرزى

دادهها و متغير ها

هدف اين يزوهش، قيمتكذارى كاز طبيعى بر مبناى هزينههاى اجتماعى ناشى از كربن براى شركت

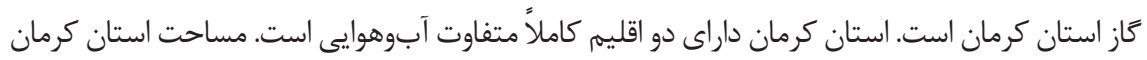
1 ITVYG و كارخانههاى بزرى يكى از استانهاى صنعتى كشور است كه مصرف انرزى بالايى دارد، كه در كنار آن،

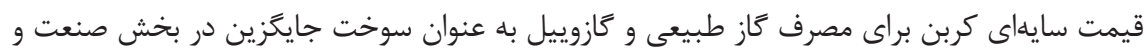

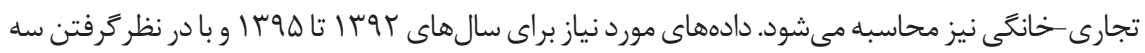

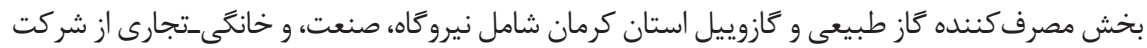

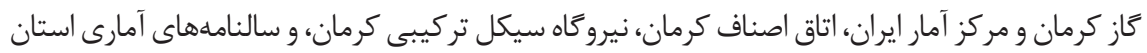

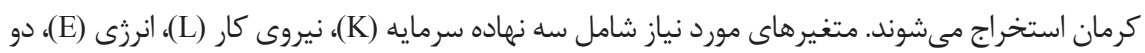

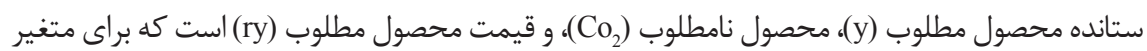

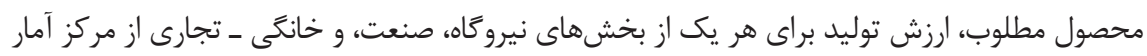
كرمان و شركت توزيع برق كرمان استخراج مىشود و به دليل در دسترس نبودن قيمت محصول مطلوب براى هر يك از بخشهاى اقتصادى از ضرب شاخص قيمت توليدكننده در سمهم ارزشافزونه بخشها از كل ارزشافزوده كشور به عنوان قيمت محصول مطلوب استفاده مىشود.

\section{نتايج تخمين}

مدل برنامهريزى غيرخطى با استفاده از نسخه بr نرمافزار گمز حل مىشود. مقدار تابع هدف و مقادير

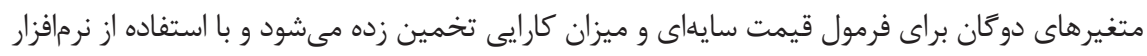

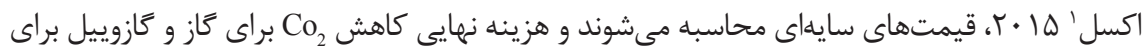

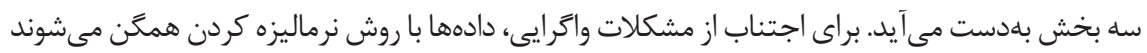

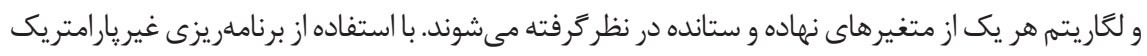

\section{Excel}


و با توجه به قيود بالا، نتايج اجراى مدل در نرمافزار گمز در ادامه ارائه مىشود:

مقادير كارايى هر بخش

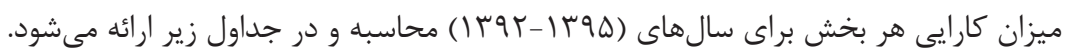

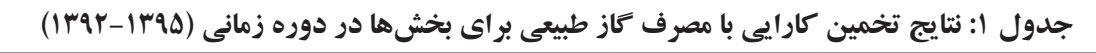

\begin{tabular}{|c|c|c|c|c|}
\hline $1 \pi 9 \Delta$ & irgp & Irar & irar & مقدار \\
\hline . /VTr & $\cdot / \pi \Delta \cdot$ & $\cdot|f|$ & $\cdot|q|$ & بخش نيروكاه \\
\hline$\cdot 1 \cdot 1 \mathrm{~F}$ &. $\mid a q V$ &.$/ 1 T Y$ & D & بخش صنعت \\
\hline.$/ 9 \wedge \Delta$ & $\cdot / \& \Delta \Lambda$ &.$/ r q 4$ & $\cdot / T \Delta \varphi$ & بخش خانكَى _تجارى \\
\hline
\end{tabular}

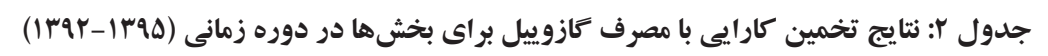

\begin{tabular}{|c|c|c|c|c|}
\hline $1 \% q \Delta$ & irap & Irar & irar & مقدار \\
\hline$\cdot \mid 9 \vee \Delta$ & $\cdot / l \mathrm{~F}$. & . &.$/ 99$ & بخش نيروكاه \\
\hline$\cdot / T r D$ & $\cdot / \cdot r$ & $.1 \cdot 9$ & $.1 \cdot .4$ & بخش صنعت \\
\hline .191 & .1919 & $\cdot|f V|$ & . JAN & بخش خانكى ـ تجارى \\
\hline
\end{tabular}

هزينه نهايى كاهش Co

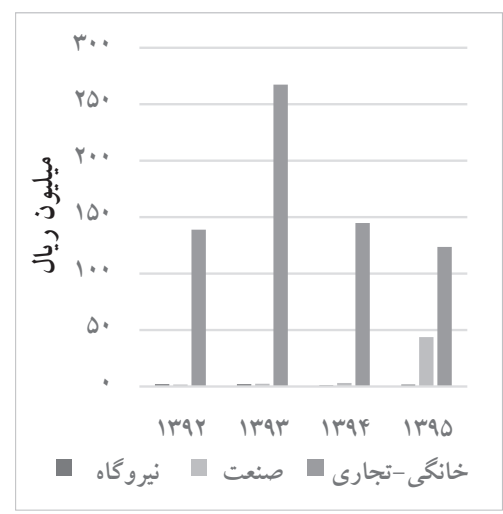

نمودار r: قيمت سايهاى كربن كازوييل (تن)

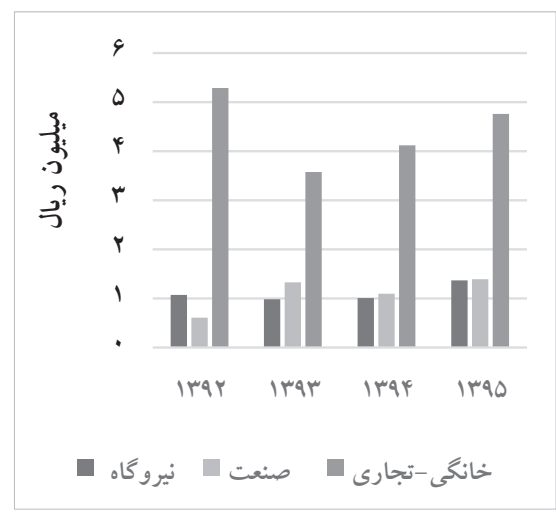

نمودار ا: قيمت سايهاى كربن كاز طبيعى (تن) 
نمودار ( () و (ז)، قيمت سايهاى كربن سه بخش ناشى از مصرف گاز طبيعى را در دوره زمانى

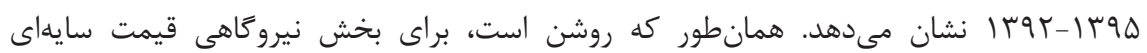

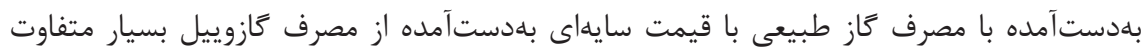

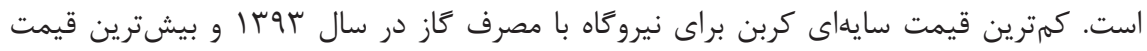

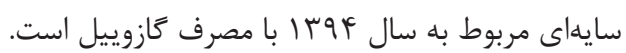

\section{قيمت تمامشده كَاز تحويلى و كَازوييل براى سه بخش}

يس از بهدستآوردن قيمت سايهاى هر بخش با مصرف گاز و كازوييل با واحد ميليون BTU،

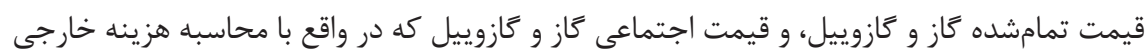
آلودگى است، محاسبه مىشود. جون در قيمت تحويلى گاز در ايران يارانه وجود دارد، براى محاس محاسبه

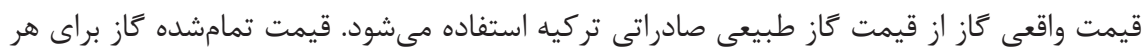

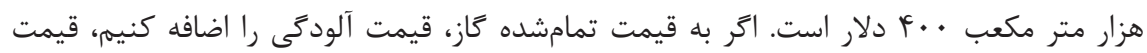

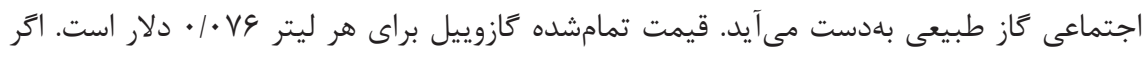
به قيمت تمامشده كازوييل قيمت آلودگى كربن را اضافه كنيم، قيمت اجتماعى كازوييل با محاسبه

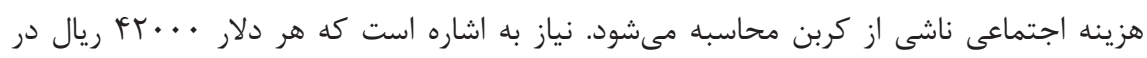

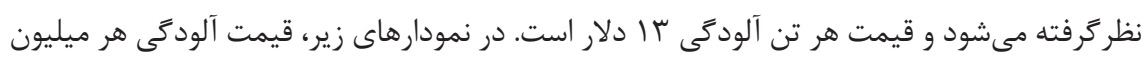
BTU مصرف Fاز و كازوييل و قيمت تمامشده ناشى از مصرف يك ميليون BTU به ريال ارائه مى شىود.

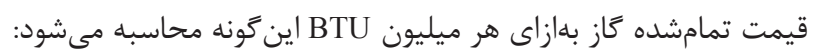

نياز به اشاره است كه هر متر مكعب كاز طبيعى با قيمت \& • • دلار بر اساس قيمت صادراتى تركيه

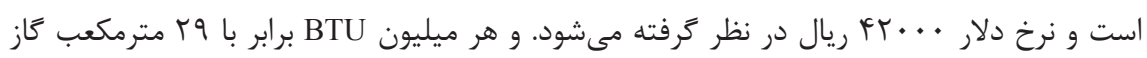

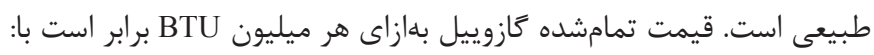

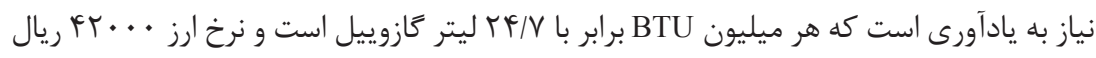

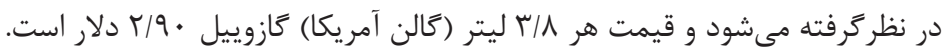



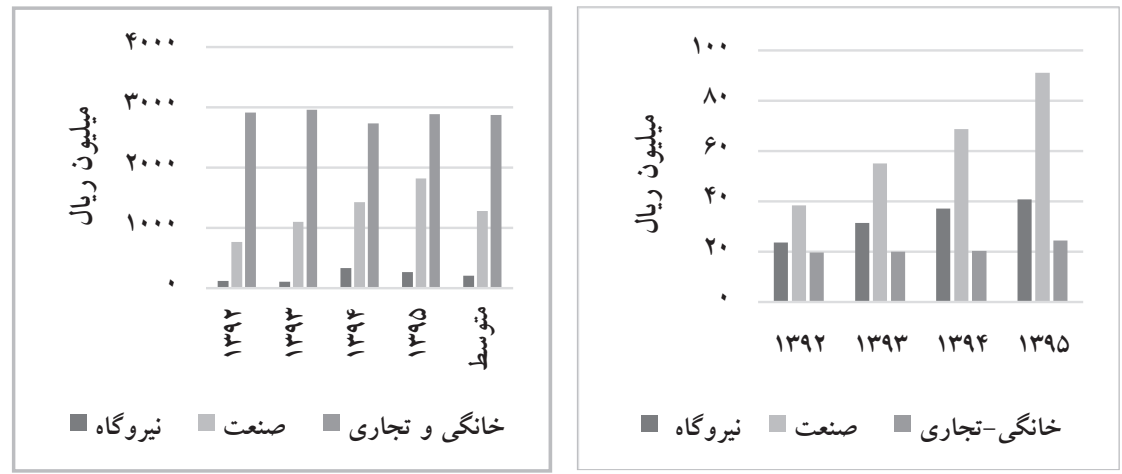

نمودار بّ: قيمت تمامشده كاز طبيعى (ميليون BTU) نمودار †: قيمت تمامشده كازوييل (ميليون BTU)

روند تغييرها براى قيمت تمامشده گاز برحسب ميليون BTU براى سه بخش صعودى است كه با محاسبه هزينه نهايى برحسب ميليون BTU براى سه بخش، غيرمشابه و متفاوت است. روند تغييرهاى قيمت اجتماعى كاز براى دو بخش نيروگاه و صنعت همواره صعودى است و روند تغييرها براى بخش خانكى_تجارى تا

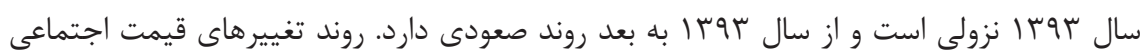
كازوييل براى بخش صنعت همواره صعودى است و براى دو بخش نيروگًاه و خانكى_تجارى از روند

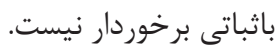

قيمت اجتماعى كاز طبيعى و كازوييل براى سه بخش

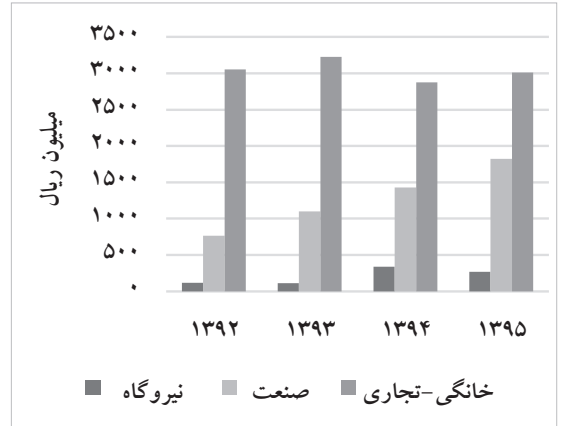

نمودار و: قيمت اجتماعى كازوييل (ميليون BTU)

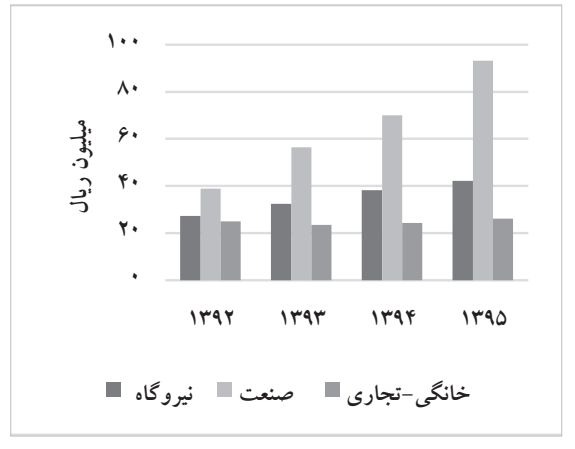

نمودار ه: قيمت اجتماعى كاز طبيعى (ميليون BTU) 


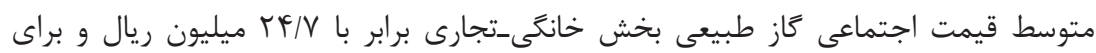

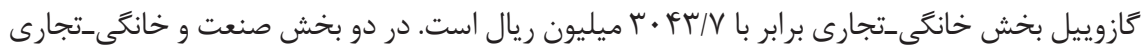

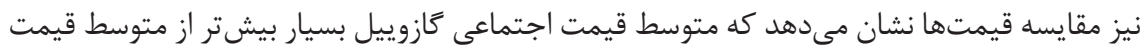
اجتماعى كاز است كه ناشى از قيمت بالاى آلودكى كازوييل است.

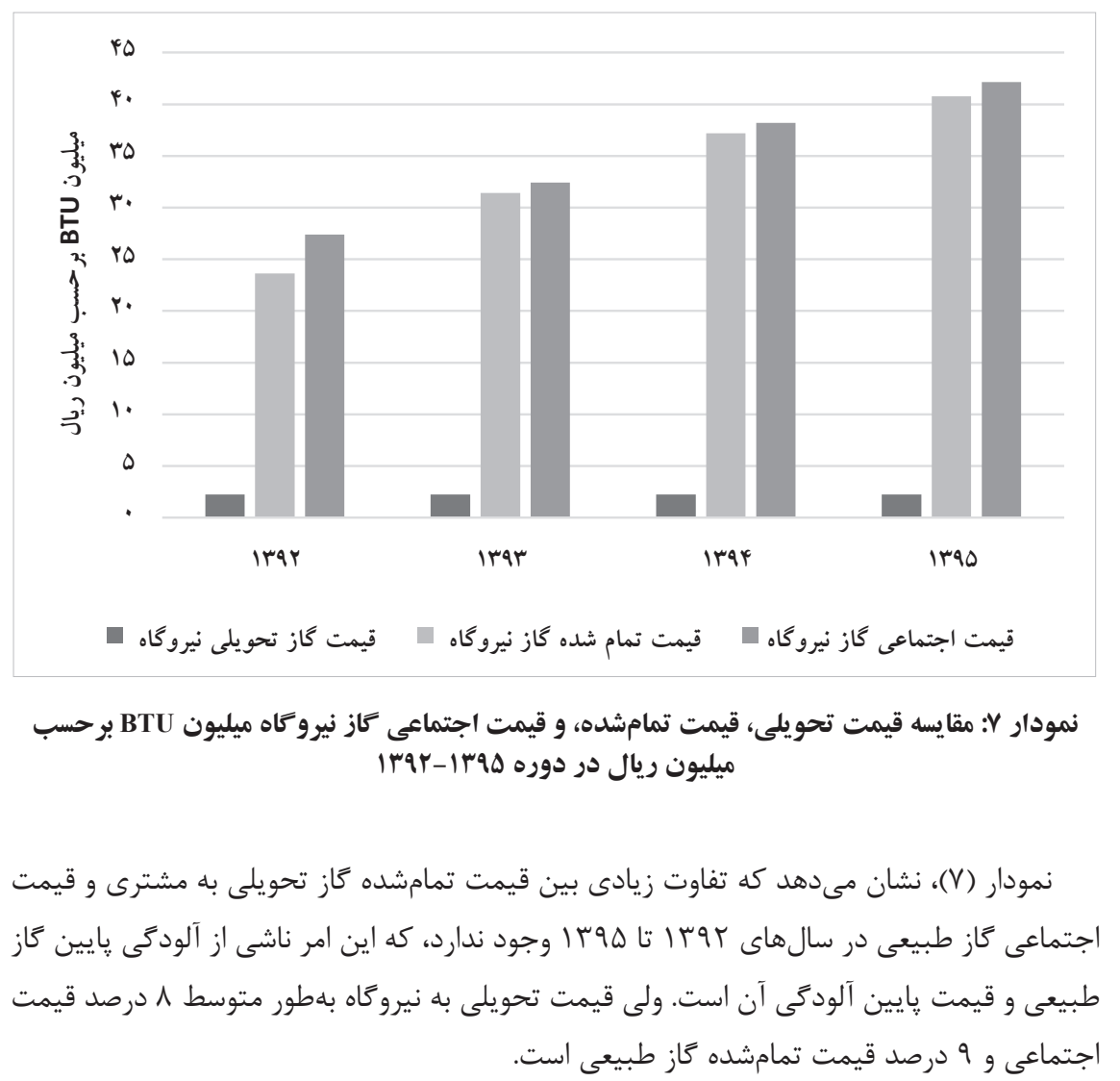




\section{بحث و نتيجه كيرى}

هدف اين يزوهش، تخمين هزينه نهايى كاهش كربن بر اساس قيمتخذارى كاز طبيعى در استان كرمان است. متغيرهاى مورد نياز شامل موجودى سرمايه، نيروى كار، ميزان مصرف انرزى، ارزشافزئ تروده

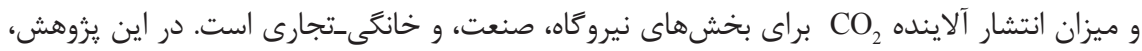
تابع فاصلهاى جهتدار با قيودش معرفى مىشود. يس از برآورد مدل برنامهريزى غيرخطى، با توجه به تخمين تابع هدف و مقادير متغيرهاى دوكان تابع فاصلهاى جهت

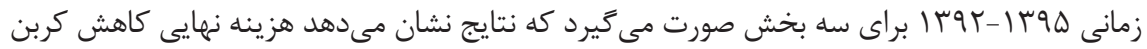

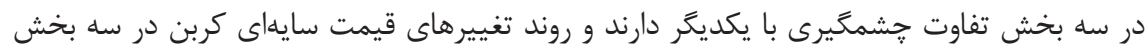
بسيار متفاوت است. قيمت سايهاى بلدستآمده براى بخش نيرو

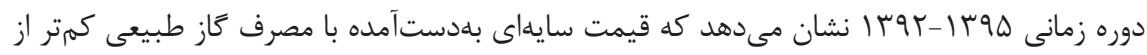

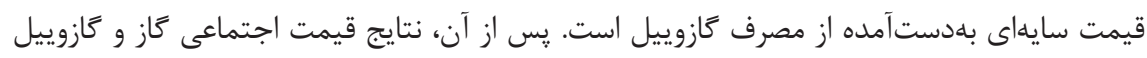
كه با محاسبه قيمت آلودگى بهدست مى آيد، نشان مىدهد كه قيمت اجتماعى نيروگاهها در سال هاى

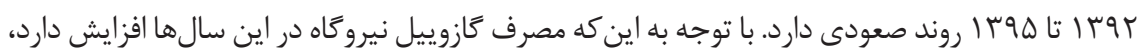

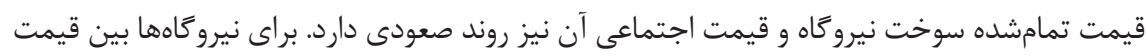

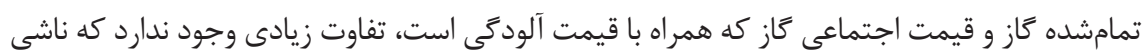

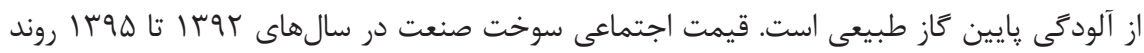
صعودى دارد. قيمت تمامشده سوخت صنعت نيز در اين سالها صعودى است. علاوه بر اين، براى بخش ستر

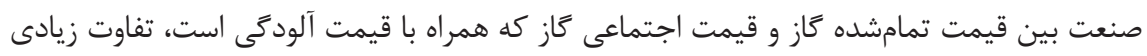
وجود ندارد كه ناشى از آلودگى يايين گاز طبيعى است. مقدار آلودگى ناشى از گَازوييل بسيار بالاتر از

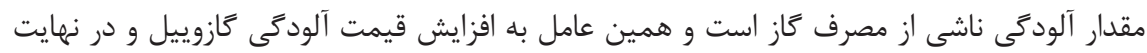

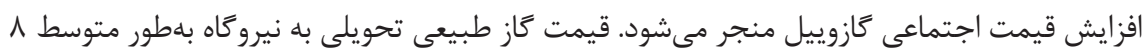

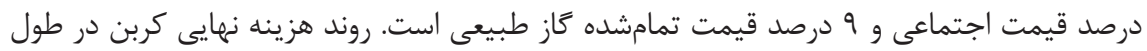

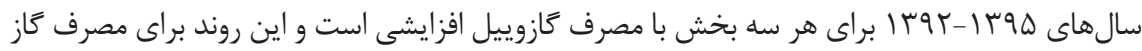
طبيعى هر سه بخش بخش خانكى -تجارى همواره كمتر از مصرف كازوييل است. در واقع، ميزان آلودگى بـى

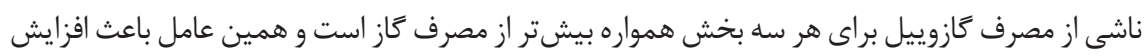

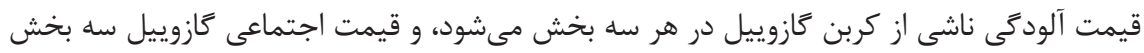
بسيار بالاتر از قيمت اجتماعى كاز طبيعى در اين سال هاست. 
همانطور كه در بخش نتايج مشخص مىشود، مقدار اين هزينه و قيمتگذارى با استفاده از رانت

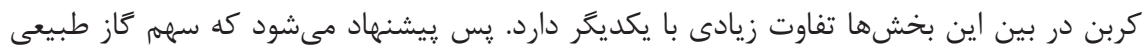

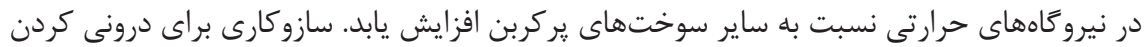

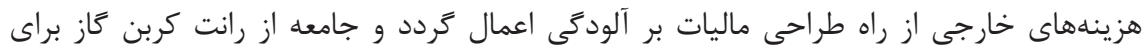

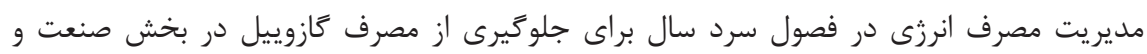

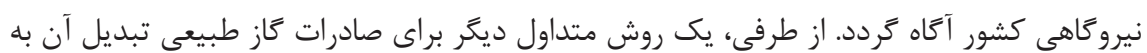
برق و صادرات برق است. جون مقدار آلودگى گاز طبيعى يايين است، صادرات گاز طبيعى با تبديل

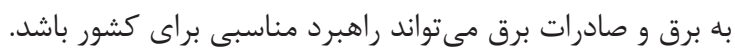

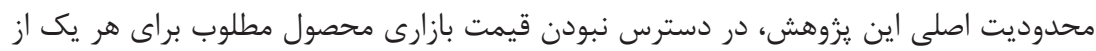
سه بخش است. براى اين منظور، از ضرب شاخص قيمت توليدكننده در سهم ارزشافزوده هر يك از بخشها به عنوان قيمت محصول مطلوب استفاده شده است.

اسماعيلى، عبدالكريم، و محسنيور، رباب (1 (INV). تعيين قيمت سايهاى آلايندهاى هوا در نيروكاههاى كشور.

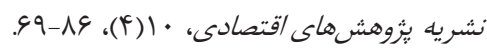

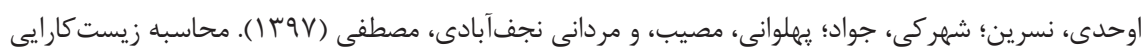

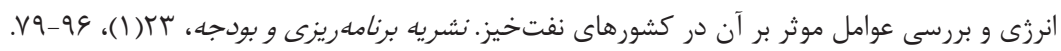

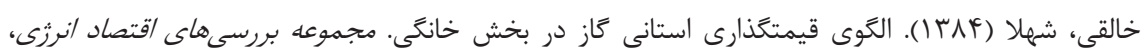
TY-YY (1))

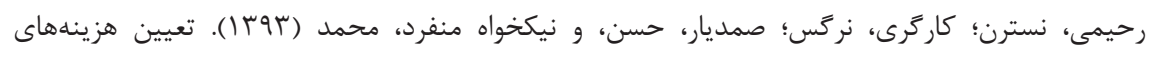
اجتماعى (خارجى) انتشار

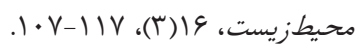

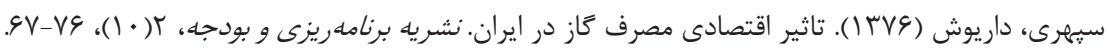

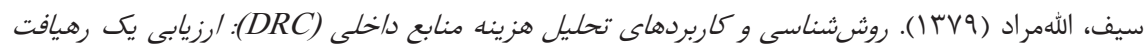

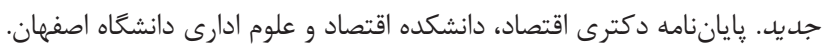

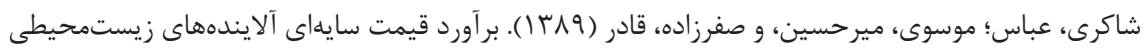
I I $\mathrm{NO}_{\mathrm{X}}$ ، $\mathrm{CO}_{2}$ ، $\mathrm{SO}_{2}$

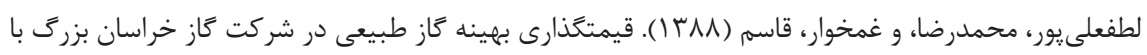




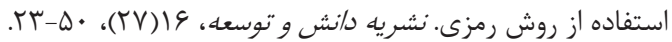

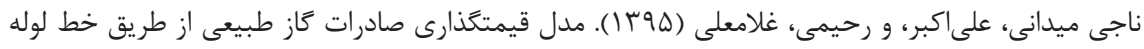

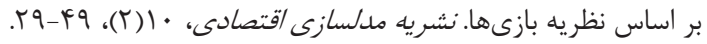

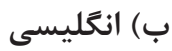

Aguilera, R. F. (2014). The Role of Natural Gas in a Low Carbon Asia Pacific. Applied Energy, 113(1), 1795-1800.

Bacon, R. W., \& Bhattacharya, S. (2007). Growth and CO2 Emissions: How Do Different Countries Fare? The World Bank Environmental Department, Environmental Department Papers, 113-120.

Boyd, G., Molburg, J., \& Prince, R. (1996). Alternative Methods of Marginal Abatement Cost Estimation: Non-Parametric Distance Functions. (No. ANL/DIS/CP-90838; CONF-9610179-3). Argonne National Lab., IL (United States). Decision and Information Sciences Div.

BP (2018). BP Statistical Review of World Energy. BP Statistical Review, London, UK, Accessed Aug, 6, 2018

Choi, Y., Zhang, N., \& Zhou, P. (2012). Efficiency and Abatement Costs of Energy-Related CO2 Emissions in China: A Slacks-Based Efficiency Measure. Applied Energy, 98(1), 198-208.

Chung, Y. H., Färe, R., \& Grosskopf, S. (1997). Productivity and Undesirable Outputs: A Directional Distance Function Approach. Journal of Environmental Management, 51(3), 229-240.

Du, L., Hanley, A., \& Wei, C. (2015). Estimating the Marginal Abatement Cost Curve of CO2 Emissions in China: Provincial Panel Data Analysis. Energy Economics, 48(1), 217-229.

Duan, Y., Li, N., Mu, H., \& Li, L. (2017). Research on Provincial Shadow Price of Carbon Dioxide in China's Iron and Steel Industry. Energy Procedia, 142(1), 2335-2340.

Energy Information Administration (EIA), U. S. (2017). Annual Energy Outlook 2015: With Projections to 2040.

Färe, R., \& Grosskopf, S. (2000). Theory and Application of Directional Distance Functions. Journal of Productivity Analysis, 13(2), 93-103.

Färe, R., Grosskopf, S., Noh, D.-W., \& Weber, W. (2005). Characteristics of a Polluting Technology: Theory and Practice. Journal of Econometrics, 126(2), 469-492.

Gallaher, M., Delhotal, C., \& Petrusa, J. (2005). Region-Specific Marginal Abatement Costs for Methane from Coal, Natural Gas, and Landfills through. 2030 Greenhouse Gas Control Technologies 7 (pp. 851-859): Elsevier.

Hailu, A., \& Veeman, T. S. (2000). Environmentally Sensitive Productivity Analysis of the Canadian Pulp and Paper Industry, 1959-1994: An Input Distance Function Approach. Journal of Environmental Economics and Management, 40(3), 251-274.

Hailu, A., \& Veeman, T. S. (2001). Non-Parametric Productivity Analysis with Undesirable Outputs: An Application to the Canadian Pulp and Paper Industry. American Journal of 
Agricultural Economics, 83(3), 605-616.

Hamilton, C., \& Turton, H. (2002). Determinants of Emissions Growth in OECD Countries. Energy Policy, 30(1), 63-71.

Lee, C.-Y., \& Zhou, P. (2015). Directional Shadow Price Estimation of CO2, SO2 and NOx in the United States Coal Power Industry 1990-2010. Energy Economics, 51(1), 493-502.

Lise, W. (2006). Decomposition of CO2 Emissions Over 1980-2003 in Turkey. Energy Policy, 34(14), 1841-1852.

Wang, Q., Cui, Q., Zhou, D., \& Wang, S. (2011). Marginal Abatement Costs of Carbon Dioxide in China: A Nonparametric Analysis. Energy Procedia, 5(1), 2316-2320.

Yang, X., Li, H., Wallin, F., Yu, Z., \& Wang, Z. (2017). Impacts of Emission Reduction and External Cost on Natural Gas Distribution. Applied Energy, 207(1), 553-561.

Zhang, M., Mu, H., Ning, Y., \& Song, Y. (2009). Decomposition of Energy-Related CO2 Emission Over 1991-2006 in China. Ecological Economics, 68(7), 2122-2128.

Zhou, P., Zhou, X., \& Fan, L. (2014). On Estimating Shadow Prices of Undesirable Outputs With Efficiency Models: A Literature Review. Applied Energy, 130(1), 799-806.

Zhou, X., Fan, L., \& Zhou, P. (2015). Marginal CO2 Abatement Costs: Findings from Alternative Shadow Price Estimates for Shanghai Industrial Sectors. Energy Policy, 77(1), 109-117.

\begin{tabular}{|c|c|c|c|c|}
\hline \multicolumn{5}{|c|}{ 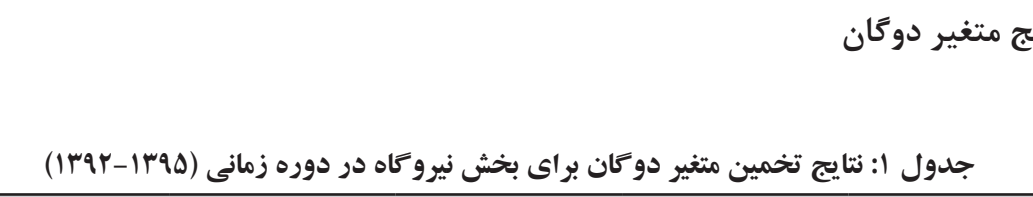 } \\
\hline Irad & Iraf & Irqu & rrar & متغير دوكان \\
\hline$\cdot / l F \wedge$ & $\cdot / 1 \Lambda$. & $\cdot / I V r$ &.$/ 191$ & $\mathrm{~L}$ \\
\hline$\cdot / \cdot 1$ & $r / \cdot r \Delta$ & $1 / 9 \wedge \Delta$ & $r / l f$. & $\mathrm{E}$ \\
\hline $1 / \wedge 91$ & $G / \Delta \Delta \varphi$ & $\Delta / \mu / F$ & $9 / 1 \vee 9$ & $\mathrm{~K}$ \\
\hline N/qIV & $9 / \pi \Delta$. & $\Lambda / \vee \Delta \Delta$ & N/GGT & $\mathrm{Y}$ \\
\hline $1 \cdot \mid g k r$ & N/TKM & $N / \cdot 9 V$ & $N / \cdot 9 \mathrm{~V}$ & $\mathrm{~b}$ \\
\hline
\end{tabular}




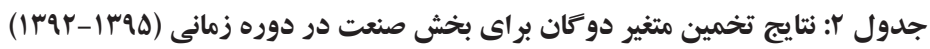

\begin{tabular}{|c|c|c|c|c|}
\hline $1 \pi 9 \Delta$ & irqf & Irar & Irqr & متغيردو \\
\hline . &.$/ I F F$ & . &.$/ 11 \mathrm{~V}$ & $\mathrm{~L}$ \\
\hline $19 / \cdot 499$ & IN/VGFT & $|N / D F T|$ & $|V / D|<q$ & $\mathrm{E}$ \\
\hline $9 / r \wedge \& \wedge$ & $V / r G \cdot r$ & V/GYIV & $11 / 9449$ & K \\
\hline $1 N / I V$. & IV/99V & $1 N / T \cdot 9$ & IVIDGY & Y \\
\hline 191111 & ID/ATA & $\mid Q / \varepsilon \cdot V$ & $\mid \Delta / T F \Delta$ & B \\
\hline
\end{tabular}

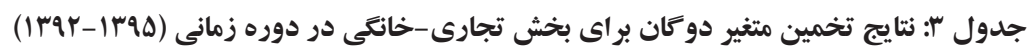

\begin{tabular}{|c|c|c|c|c|}
\hline 1190 & Irqp & rar & irar & متغير دوكان \\
\hline - /VqF & $\cdot / 1 \wedge$. &.$/ 9 \Delta T$ & $\cdot / \cdot \Delta F$ & $\mathrm{~L}$ \\
\hline$\cdot / \cdot \Delta V$ & $\cdot T / \cdot F Q$ & $\cdot / \cdot \Delta V$ & سז•|• & $\mathrm{E}$ \\
\hline$\Gamma / \cdot I V$ & $\varepsilon / \Delta \Delta \varphi$ & F/rVr & 11/EFFq & K \\
\hline 1ध/Drq & $q / r \Delta \cdot$ & $I V / \cdot T V$ & $V / \Delta V V$ & $\mathrm{Y}$ \\
\hline $\mid F / G G 4$ & NTRM & $\mid F / \Delta q F$ & $\mid F / \Delta v q$ & B \\
\hline
\end{tabular}

نتايج بالا كه با استفاده از نرمافزار گمز ارائه مىشوند، برآورد متغير دوكان متناظر با قيود مربوط

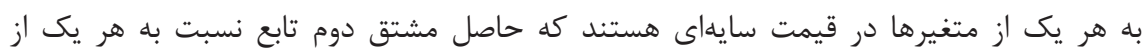

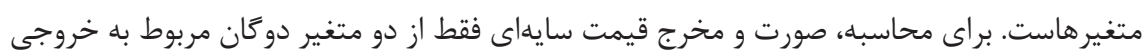
مطلوب و خروجى نامطلوب استفاده مىشود. 